\title{
Relational Language as a Mitigating Device
}

Igor Ivanović, Faculty of Philology, University of Montenegro, iggybosnia@ucg.ac.me

\begin{abstract}
In this paper, we will identify and discuss the notion of relational language. We will be able to see how high frequency chunks and words in the spoken corpora are tasked with pragmatic functions dealing with the speakerlistener relationship and the management of, in our case, two-way mediated shop conversations, specifically in terms of maintaining good relations. These frequent lexical items point to the extent to which speakers interact with each other on the interactive plane. The abovementioned notions will be applied to the analysis of the corpus, which consists of transcribed recordings of agentcustomer communications in English language. Those communications are related to different services owned by a telecommunication company present in Montenegro.
\end{abstract}

Keywords: relational language, mitigating devices, hedging, vagueness, approximation

\section{Introduction}

In this paper we will be discussing the idea of how to convey relational meaning and what mitigating devices are typically used within the context of agent-customer communication. We chose this communication environment and context in order to show how relational language is about building long-term company-customer relationships. For this purpose, we have selected two-way mediated shop conversations in English language through which we will try to show the two principal qualities or features of mitigating devices: tentativeness and indirectness. The relevance of this question at hand is that in our everyday communication we use relational language as a mitigating device more or less consciously. This is primarily done in order to achieve a linguistic or communication goal through, for example, conveying your message more or less explicitly/implicitly. The main hypothesis of this paper is that shop conversations will principally use indirectness and tentativeness as mitigating devices. This means hearer will almost always be involved in a speech act which needs to be decoded through the inferential process and this will be facilitated 
by both addressee-oriented and speaker-oriented distancing and reservations. In this manner both agents and customers can preserve face if they feel threatened by the act found within the message. This means both transactional and relational goals of communication need to be taken into account and not treated as exclusively dichotomous. In order to test this hypothesis, we have collected a corpus of agentcustomer conversations in English.

\section{Corpus collection and transcription; sound files and related text transcriptions}

The data was recorded using a digital voice recorder and a bidirectional microphone. The bidirectional microphone was selected because of its figure-8 polar plot which is optimal for spatial distribution of the participants. The speech of each participant was recorded at a sampling rate of $44100 \mathrm{~Hz}$ (16 bit) using the E-MU's 0404 USB 2.0 Audio/MIDI Interface and Adobe Audition. The agent (of the Telecommunication Company) had been made aware of the presence of the voice recorder, but $s$ /he only knew the general purpose of the recording. Due to regulatory obligations defined by the Law on Protection of Personal Data, the customers were informed that they were being recorded and, in order for the recording to proceed, each customer needed to sign a consent form. The digital recordings of the collected conversations between agents and customers were transferred onto a laptop using a digital $1 / O$ card. This $1 / O$ card was used in order to preserve the quality of the recordings since in this manner we eliminated the need to resample the recordings using an A/D card. Such resampling would, most probably, introduce additional noise into the speech files. The recorded agent-customer conversations were transcribed into written English text by our ${ }^{1}$ undergraduate transcribers using Soundscriber ${ }^{2}$ software. These transcripts are stored as ASCII text files together with the sound files. Our research assistants corrected errors in the automatic transcription of conversations. Recordings lasted for about 8 minutes per day (10 days in total), yielding around 3.5 minutes, per day, of analysable speech, once silences, fillers, non-speech sounds such as laughter and sections with background noise had been eliminated.

\footnotetext{
${ }^{1}$ Faculty name removed due to legal requirements.

${ }^{2}$ http://www-personal.umich.edu/ ebreck/code/sscriber/
} 


\section{Model and parameters of communication}

A necessary prerequisite before looking into our empirical data is to define the model of communication, which is mostly revolving around the traditional dyadic speaker-hearer model of communication with some necessary amendments, required in order to fully accommodate agent-customer encounters.

As far as our paper is concerned, the communicative parameters (traditional paradigm) are as follows:

- For the sake of this paper, we will limit ourselves to EnglishEnglish conversation.

- Conversation usually takes place between two people. If more people are present, they are very often passivised.

- These encounters usually have a largely passive audience which can react, but such interjections normally have no bearing on the ongoing interaction.

- The participants often do not know each other.

- Almost invariably, one of the participants (the agent) has more knowledge, thus $s /$ he is able to exercise additional discourse rights in terms of opening/closing topics and controlling turntaking.

Additional communicative parameters, which must be taken into account due to the specific nature of the encounters, are as follows:

- Audience is potentially volatile, meaning there may be an extremely dissatisfied customer. Hence, the agent needs to deescalate such situations and employ different communicative strategies in order to do so (understanding, support, reassurance, face preservation, etc.).

- The roles of speaker, hearer and addressee are sometimes ambiguous because of "half listening", talking at the same time, etc. So, if the conditions allow, these roles can interchange.

All of the communicative events from our corpus presuppose a certain degree of institutionalisation, although the agent will almost always try to present him/herself as a "warm" human being, rather than the "cold" company's official. The mentioned degree of institutionalisation is necessary because it is in the company's interest to have precedents for communication, rather than having to face each interaction as something novel and potentially threatening. The elements, which make these potentially threatening encounters less threatening, are the elements stemming from relational language. 


\section{Relational language with examples from the corpus}

For the purposes of our paper, we will analyse the abovementioned transcribed conversations between agents and customers and see why relational language is important for both agents and customers.

Relational language, as the name suggests, has the main purpose of establishing and maintaining satisfactory relations between the speaker and the listener. Such satisfactory relations often have casual effects and may bring about changes in our attitudes, values, beliefs, etc. These changes are brought about within social events which are composed of multiple interactive processes of meaning-making. The main pragmatic categories of relational language refer to the preservation of face, the expression of politeness, (un)intentional vagueness and discourse marking. On the other hand, transactional language denotes the language which is related to the exchange of information between the speakers. However, what needs to be clarified, is the fact that not all language can be strictly divided into these two broad functional categories. We may freely say that transactional interactions are almost invariably interspersed with relational language and vice versa. lacobucci (lacobucci 91), who analysed customer calls to a phone company talks about the integration of relational-oriented talk and the transactional tasks. Moreover, Cheepen (Cheepen 301) came to the conclusion that even the most extreme examples of relational dialogues were interwoven with task-oriented interactions and, along the similar reasoning, even the most extreme examples of transactional dialogues were likely to contain person-oriented interactions.

Table 1: Functional categories of relational language with their pragmatic functions

\begin{tabular}{|l|l|}
\hline Relational language features & Corpus examples \\
\hline Face and politeness & $\begin{array}{l}\text { Do you think you can give me } \\
\text { the number of this company, } \\
\text { I am not quite sure about its } \\
\text { name, but if we...? }\end{array}$ \\
\hline Vagueness and approximation & $\begin{array}{l}\ldots \text { whatever, I am more than } \\
\text { glad to help with that sort of } \\
\text { things... }\end{array}$ \\
\hline Discourse marking & $\begin{array}{l}\text { Right, if we cannot find that } \\
\text { street, we can ask around, } \\
\text { you know what I mean? }\end{array}$ \\
\hline Endearment & I would need three SIM cards \\
\hline
\end{tabular}




\begin{tabular}{|c|c|c|}
\hline & & darling. \\
\hline Hedging & & $\begin{array}{l}\text { Do you happen to have this } \\
\text { model of phone? } \\
\text { To be honest, I don't know. }\end{array}$ \\
\hline Small talk & & Lovely, isn't it? \\
\hline & Thanking & Thanks a lot. \\
\hline Conversational & Leave-taking & Bye. \\
\hline routines & $\begin{array}{l}\text { Requestive } \\
\text { routine }\end{array}$ & Can I have this one? \\
\hline
\end{tabular}

Corpus examples:

Encounter 1:

$\mathrm{S}_{1}$ : I would need three SIM cards darling.

$\mathrm{S}_{2}$ : That would be for you and your family, I guess. I will gladly help you.

$\mathrm{S}_{1}$ : That would be lovely.

$\ldots$

$\mathrm{S}_{1}$ : Please sign here. Thanks. (giving her the contract and SIM cards)

$\mathrm{S}_{2}$ : Thanks!

$\mathrm{S}_{1}$ : Have a lovely day!

$\mathrm{S}_{2}$ : Bye.

Encounter 2:

$\mathrm{S}_{1}$ : Do you happen to have this model of phone? (showing her a phone with a broken screen)

$\mathrm{S}_{2}$ : Let me check, (pausing and checking the database) we don't. But we have... (interrupted)

$\mathrm{S}_{1}$ : Oh! Can I have this one? (pointing to a similar phone model) (taking the phone) Lovely, isn't it?

$\mathrm{S}_{2}$ : Lovely indeed! Ok, how do you want to pay?

$\mathrm{S}_{1}$ : Credit card, please.

$\mathrm{S}_{2}$ : Now, two hundred thirty-six point thirty-two

$\mathrm{S}_{1}$ : Thanks a lot.

$\mathrm{S}_{2}$ : No, thank you!

$\mathrm{S}_{1}$ : Bye.

$\mathrm{S}_{2}$ : Bye.

Now, let us remove relation-oriented linguistic elements (in bold) from these two encounters.

Encounter 1:

$\mathrm{S}_{1}$ : I would need three SIM cards... 
$\mathrm{S}_{2}$ : That would be for you and your family...

...

$\mathrm{S}_{1}$ : Sign here. (giving her the contract and SIM cards)

Encounter 2:

$\mathrm{S}_{1}$ : Do you happen to have this model of phone? (showing her a phone with a broken screen)

$\mathrm{S}_{2}$ : Let me check, we don't. But we have... (interrupted)

$\mathrm{S}_{1}:$...this one? (pointing to a similar phone model)

$\mathrm{S}_{2}$ : Ok, how do you want to pay?

$\mathrm{S}_{1}$ : Credit card.

$\mathrm{S}_{2}$ : Two hundred thirty-six point thirty-two.

Instead of "warm" conversation, we downgraded the communication to a "police report" style, where the conversation is kept to a bare minimum. Even though we can communicate in this manner and complete the task we set out to do, in order to establish and maintain good relations with our interlocutor, we have to modify our language style so as to attend to the relational and affective side of the interaction. For example, face and politeness are used as an indirect way to "polish out" rough speech acts such as directives (commands, requests, etc.). This is the reason why indirectness is a non-threatening way of expressing one's attitude, which can facilitate the communication and protect the face of the involved interlocutors (Strauss / Parastou 61).

Example of a "softened" speech act:

(In a store)

$\mathrm{S}_{1}$ : I would like to inquire about my email account, but I don't know if I should do that today.

Utterances, like the one above, contain chunks (I don't know if I should do that today) which can be well formed and play a pivotal role in the relational nature of the communication. Chunks are syntactic fragments, which may serve as important clues as to how communication unfolds and how interactions, shared knowledge and grammar emerge rather than being predetermined in interaction. I don't know was the most frequent chunk in our corpus, uttered by a customer. It usually serves the purpose of framing a future request for information. This gap in knowledge is usually followed by an action done by an agent with authority. In this manner, shared communicative resources are used by both a customer and an agent, which facilitates mutual approach to a problem.

The majority of the conversational turns from the examples above are interactively establishing that the precondition for achieving a desired 
social and practical outcome are met, i.e. that the customer is able to resolve his/her problems. Apart from that, the above examples suggest that we can talk about three distinctive elements in meaning-making processes: information production, the information itself and information reception. In the context of the communication between a customer and an agent, the production of the information establishes a common social ground and places emphasis on the producer of such information. The information itself is usually there in order to trigger reactions from an agent or somebody on the other side, representing the company. The reception of the information places the focus on the listener.

\section{Conversational routines}

Conversational routines (Coulmas 9) are formulaic utterances which may serve numerous functions, one of them being "pseudo-intimacy" (O'Keeffe 25). Pseudo-intimacy can be established if we introduce utterances which are recurrent, function within the framework of established colligations and serve pragmatically specialised functions. How such pragmatically specialised functions operate can be seen from our recordings pertaining to Help Desk ${ }^{3}$.

Agent's ${ }^{4}$ response at the end of the interaction:

...thank you for your... Your (name of the company) ... We are pleased to have you as one of our customers.

The use of pronouns (you, us) and an attributive adjective (your) implies familiarity and inclusiveness which is the relational function of this communication-closing pattern. These pronouns maintain a sense of commonality between people with a real common bond. Notice that even the company is "yours".

Table 2: Concordance lines of thank you for your from our corpora of recorded conversations (AntConc 3.4.4 $\mathrm{w}^{5}$ )

1. it should be enabled in several minutes. THANK YOU FOR YOUR application, I will try to [INB $]^{6}$

\footnotetext{
${ }^{3}$ This is one of the services offered by a telecommunication company and it primarily functions as a resource intended to provide the customer or end user with information and support related to a company's or institution's products and services.

${ }^{4}$ Generic name for all Help Desk employees.

${ }^{5}$ http://www.laurenceanthony.net/software/antconc/

${ }^{6}$ INB refers to inbound communication (customer-initiated communication towards the company, such as complaint, suggestions, general and specific
} 
2. next week to discuss possible openings. THANK YOU FOR YOUR consideration. [INB]

3. the end of the contract: THANK YOU FOR YOUR cooperation with the [OUTB]

4. Does this sound like a good offer to you? Well, THANK YOU FOR YOUR question. [INB]

5. these people to communicate. So I THANK YOU FOR YOUR ideas, but remember [INB]

6. very well indeed. And I THANK YOU FOR YOUR advice. But I think I [OUTB]

7. to hear us when we talk. We THANK YOU FOR YOUR prompt response, so [INB]

8. not quite good, but still manageable, once again THANK YOU FOR YOUR time and [INB]

9. specific questions if you wish. Err, but THANK YOU FOR YOUR time [INB]

10. and, better still, let's build on it. THANK YOU FOR YOUR understanding [INB]

11. support the customers in so many ways. THANK YOU FOR YOUR help and guidance. So [INB]

This was the most frequent example in our corpus consisting of recorded conversations. Its equivalent (in frequency and execution of specialised functions) is the pattern would you like to which is a commissive conversational routine used for offering and, at the same time, phrase used as a selling device. We must not forget we are dealing with the corpus mainly consisting of words, chunks, patterns or phrases, which are highly specialised in terms of their appeal to customers. Therefore, the company will always try to draw a horizontal line between the members of a dyad.

Table 3: Concordance lines from the corpus (AntConc 3.4.4w)

1. gonna say if you keep doing that. WOULD YOU LIKE TO sign now and pay later?

2. you had your, err, router serviced? Is it ready for doing? WOULD YOU LIKE TO take effectively?

3. dismal day but I quite like a little. That one's not drive. WOULD YOU LIKE TO go to

information, etc.), OUTB refers to outbound communication (companyinitiated communication to a customer, such as offers, promotions, sales, etc.). 
4. quite sure how all the ones go. I think everyone knows. WOULD YOU LIKE TO pay?

5. Yeah, yeah do you know what is? WOULD YOU LIKE TO say that one more time please?

6. Okay and perhaps, erm, perhaps you'd also like to...WOULD YOU LIKE TO look at this side of

7. 's amazing! Sixty-two say yes, thirty-five no. Of the no's, WOULD YOU LIKE TO say why you

8. just now, because we're going to do that, WOULD YOU LIKE TO put some additional

9. out a few of the brilliant ideas. Share them with people. WOULD YOU LIKE TO start? Erm,

10. the previous customer and he got them out and said WOULD YOU LIKE TO go and right I'll put

11. about this in Help Desk and let you know. Okay? Okay, WOULD YOU LIKE TO sign

As we can see from these examples, such commissive conversational routine is behaving as a situation-bound idiom, which serves a specific pragmatic function in terms of maintaining good relations within the conversational cluster composed of the company and a customer.

Other chunks found in our corpus were mostly related to the routines or speech acts of requesting and offering, since we must not forget the company's ultimate goal is to sell its products or services. Generally, such speech acts can be put under two speech act categories: directives and commissives. Directives are speech acts where the speaker wants to "direct" the hearer in a desired direction, which is mainly realised through insisting, instructing, permitting, and requesting. Commissives are speech acts where the speaker accepts the course of activities stemming from such activities, such as guaranteeing, undertaking and promising.

In our corpus, the second most frequent chunk was Is that what you want which serves a social routine or ritual (Goffman 13), protecting the negative face of the hearer or offering the hearer a chance to refuse an offer without loss of face:

$\mathrm{S}_{1}$ : This is the newest offer, which will replace your current data plan. Is that what you want?

$\mathrm{S}_{2}$ : Yes, because I don't want to use roaming any more.

$\mathrm{S}_{1}$ : Okay. Fine.

Such a chunk can be used to soften the imposition of the request:

$\mathrm{S}_{1}$ : I will kindly ask you to refrain from using your phone for some time.

$\mathrm{S}_{2}$ : If I have to... 
$\mathrm{S}_{1}$ : Is that what you want?

$\mathrm{S}_{2}$ : Yeah.

\section{Hedging}

Hedging has been defined by various authors, but the very term was coined by Lakoff in 1972 (Lakoff 218) in order to define the semantic concept whereby certain words and phrases become fuzzier or less fuzzy than they would usually be. Hedging, as a mitigating device, is generally used to soften the impact of negative statements, thus making them operate as face-saving devices (Channell 98) and serve as pragmatic markers:

Hedged sentence:

$\mathrm{S}_{1}$ : I guess we can fix the problem in less than $24 \mathrm{~h}$, err... there is a possibility we will be able to do it sooner.

$\mathrm{S}_{2}$ : I would appreciate that, since my son is really getting irritated...

Unhedged sentence:

$\mathrm{S}_{1}$ : We can fix the problem in less than $24 \mathrm{~h}$, err... we will be able to do it sooner.

Without hedging, the agent is running the risk his/her time frame for fixing the problem may not be respected (it is beyond the agent's control), leading to an even higher level of dissatisfaction with the customer, which is certainly an undesired outcome. This is the reason why hedging is trying to mitigate and downtone utterances. This is particularly true for speech acts such as directives, where the implication of indirectness protects the face of the interlocutors and brings into their communication non-face-threatening expressions.

Table 4: The most common forms of hedges in the corpus

\begin{tabular}{|l|l|}
\hline Most common group & Examples \\
\hline $\begin{array}{l}\text { Modal verbs and verbs with } \\
\text { modal meaning }\end{array}$ & $\begin{array}{l}\text { I suppose you are right, since the } \\
\text { IP is still in experimental phase. }\end{array}$ \\
\hline Evaluative relative clauses & $\begin{array}{l}\text { You've switched off your routers, } \\
\text { which was a good thing to do... }\end{array}$ \\
\hline Restrictive adverbs & $\begin{array}{l}\text { We will need only one signature } \\
\text { and one contract, just to confirm... }\end{array}$ \\
\hline $\begin{array}{l}\text { Syntactic choices pertaining to } \\
\text { question forms }\end{array}$ & $\begin{array}{l}\text { Would you consider switching on } \\
\text { the second STB? }\end{array}$ \\
\hline $\begin{array}{l}\text { Other (stance adverbs, false } \\
\text { starts, etc.) }\end{array}$ & $\begin{array}{l}\text { Of course, it is possible to install a } \\
\text { switch... }\end{array}$ \\
\hline
\end{tabular}




\section{Chart 1: The most common forms of hedges found in our corpus}



As it can be seen from the data given above, hedging is mostly revolving around modal verbs and their semantic equivalents, since they can clearly and concisely express the desired ideas in a hedged context within interactional roles. To be more specific, the most common types of modality, also found in our corpus, are epistemic and deontic modality. The former is related to knowledge exchange, i.e. modalised statements about the speaker's commitment to the truth: "The problem with your PSTN line may be fixed in no time.", and modalised questions when a speaker wants to elicit the interlocutor's commitment to the truth: "Could we discuss my new data plan?". The latter is related to activity exchanges, i.e. modalised demands about the speaker's commitment to obligation: "You should disconnect your router and follow the on-screen instructions.", and modalised offers or the speaker's commitment to act: "You may not connect the STB and the rest of the equipment." Hidden in these data is the fact that the more asymmetrical the speaker relationship are, the more the power role holder (usually an agent, since $s /$ he possesses more knowledge/information and control over the issue resolution) will wish to downtone his/her power in order to be on equal footing with his/her listener, i.e., customer. 


\section{Approximation and vagueness}

Not being precise can, in certain encounters, enable approximators to downtone the speaker's statements and, for this purpose, prepositions and adverbs can be rather useful lexical devices (Carter / McCarthy 15). Approximation usually serves two functions. First, an approximator does not want to be overly precise and, second, s/he can come across as being too pedantic. In the context of our corpus (company vs. customer) not being precise may be very useful since an agent cannot always promise that a certain problem will be resolved at that particular time:

S: Downtime should be resolved around nine.

$\mathrm{S}$ : This sort of thing requires two different offices, which will be notified through our ticketing system.

In our corpus around and or/and that sort of things, which can be defined as a general extender (Oversteer / Yule 252) consisting of a conjunction and a noun phrase, were the most frequent vague category markers. Vague categories can be defined as socio-culturally implanted elements which serve as promoters of active cooperation of the listener (Jucker, Smith / Ludge 1751), thus reinforcing the shared knowledge and good relationship between the interlocutors:

$\mathrm{S}_{1}$ : This service cannot be installed in your area, you know?

$\mathrm{S}_{2}$ : No, why?

$\mathrm{S}_{1}$ : This service is distance-related and can only be effective within around, err, $5 \mathrm{~km}$ form a base station.

$\mathrm{S}_{2}$ : Is there an alternative to that sort of services?

$\mathrm{S}_{1}$ : I think there is.

$\mathrm{S}_{1}$ : In a couple of months we will be launching a new DSL service...

Both interlocutors use vague category markers, which shows that speakers have a certain degree of expectations about what their coparticipants know, but this degree can always be higher or lower, which is negotiated within social space. This usually means the speaker will increase the number of vague category markers if $s /$ he sees that the hearer is able to follow this vaguer conversation. Approximation and vagueness bring about assumptions, which are a pervasive property of our corpora and of considerable social importance. The most frequent types of assumptions are propositional assumptions, which deal with what may or may not happen (e.g. a service provider may or may not offer a certain service to some customers) and existential assumptions, which are assumptions about what exists (there may be a problem with a device, cable, router, etc.). The most interesting type of assumptions are conversational implicatures, which, in our corpus, usually serve as strategic avoidance of explicitness: 
$\mathrm{S}_{1}$ : I did not know your service is this bad... (trying to persuade the interlocutor to accept that the service is bad)

$\mathrm{S}_{2}$ : What do you mean?

$\mathrm{S}_{1}$ : My picture freezes on each HD channel...

Vaguer conversation facilitates the feeling of shared professional knowledge, which brings participants closer. Of course, the opposite is true if the hearer is unable to properly decode vague category markers. The following short paragraph illustrates these communicative shortcuts and "instant socio-linguistic closeness":

(Two electrical engineers discussing a problem, one as an agent, the other as a customer)

$\mathrm{S}_{1}$ : Yes, I think it is some sort of a problem with interference. (immediately narrowing down possible problems)

$\mathrm{S}_{2}$ : It would seem so, because there are a couple of energetic cables right next to ours.

$\mathrm{S}_{1}$ : Yeah, some level of service degradation...

$\mathrm{S}_{2}$ : Yeah, people like us, would know everything about that. Let me check...

In addition to what is said in the previous paragraph, it is also interesting to observe that Yeah serves to acknowledge the incoming information from the other speaker and facilitate the conversation and as such serves as a minimal response token ${ }^{7}$ which can have both grammatical and social functions. Response tokens are interjections made in response to the speaker's utterance. Let us look into some of the functions found in our corpus:

$\mathrm{S}_{1}$ : I want to report a problem about my router.

$\mathrm{S}_{2}$ : Yeah... (response token as a continuer)

$\mathrm{S}_{1}$ : The internet speed is awful and my Wi-Fi drops...

$\cdots$

$\mathrm{S}_{1}$ : ....which is why I want DSL.

$\mathrm{S}_{2}$ : Yeah! (agreement and support towards the speaker's judgement)

$\cdots$

$\mathrm{S}_{2}$ : And that disconnection is due to an interference...

$\mathrm{S}_{1}$ : Mm. (weak acknowledgement or minor addition)

$\mathrm{S}_{2}$ : Caused by new construction works next to your building.

Continuers are primarily exercised in order to keep the communication flowing, marking the speaker's desire for the conversation to continue. On the other side, $\mathrm{mm}$, when it can be understood as a weak acknowledgement or minor addition, can be a "talk-stopper" implying

\footnotetext{
${ }^{7}$ Other types are non-word vocalisations (e.g. mm, mhum) and non-minimal response tokens, such as great, absolutely, etc.
} 
disinterest and communication dead-end (Paul Gee 36). However, in the majority of cases found in our corpus, response tokens are usually placed at points where participants agree, thus facilitating collaborative effort to define topic boundaries, where such boundaries can be preserved or shifted:

$\mathrm{S}_{1}$ : This STB has software-disabled USB.

$\mathrm{S}_{2}$ : Yeah. (display of understanding, the topic should continue)

$\mathrm{S}_{1}$ : This is due to your policy aimed at preventing copyright issues.

$\mathrm{S}_{2}$ : That is true. (opinion convergence)

As well as helping to maintain the topic, these response tokens allow a conversation to end on mutually beneficial terms:

$\mathrm{S}_{1}$ : We are conducting a survey on behalf of our company to check your satisfaction with the recent visit of...

$\mathrm{S}_{2}$ : Okay, good.

$\mathrm{S}_{1}$ : What can you tell me about the response time?

$\mathrm{S}_{2}$ : Fabulous, he was here in no time.

$\mathrm{S}_{1}$ : Okay. What about professionalism?

$\mathrm{S}_{2}$ : He explained me everything, so I guess he know his job.

$\mathrm{S}_{1}$ : All right. How would you grade his customer relationship?

$\mathrm{S}_{2}$ : He was very pleasant and nice. I hope that you will always send me someone like him.

$\mathrm{S}_{1}: \mathrm{Mm}$, you never know. (laughs)

$\mathrm{S}_{2}$ : Yeah. You never know. (laughs)

$\mathrm{S}_{1}$ : Cheers.

$\mathrm{S}_{2}$ : Bye.

In this case, we can also witness clustering of response tokens, which consolidates the interpersonal relationship and provides numerous signals that the communication is about to be ended, often signalled by closing routines of confirmations and greetings. One of the response token's functions is to strike a chord at an affective level. In the dialogue above, this is an engagement token Fabulous. It indicates the addressee's heightened level of empathy, surprise, shock, etc. Thus, they register high on the affective scale. Due to its affective nature and higher level of offering positive feedback to the listener, this kind of response token has a much higher interactional level than an "ordinary" continuer. This affective level serves to mark the boundaries where the customer expresses his/her satisfaction with the provided service at an affective level of the content of the message. Our corpus contains lovely, excellent and right, which serve as the abovementioned engagement tokens with their context-specific functions. 
Another important idea when it comes to vagueness is that meaningmaking depends not only on what is explicit in the communication, but also what is implied. This is the reason why the interpretation of approximation and vagueness is a rather complex process and must be analysed from numerous different aspects. In general terms, in order to have "socially successful" approximation and vagueness, the customer should be able to properly decode what words or sentences in a particular context mean in order for such communication to have any social effect.

\section{Discourse markers}

Discourse markers are a pragmatic feature which interlinks discourse segments and serves numerous communicative functions. These include the delineation of boundaries and shifts in ongoing talk, as well as marking of responses. They belong to a wider class of pragmatic markers which denote speakers' feelings, attitudes and organisational choices (Carter / McCarthy 89). Pragmatic markers also include stance markers which express speakers' hedges and attitudes and as such encode speakers' affective reactions.

In our corpus, the most frequent chunk of all was you know which is implying at least some level of shared knowledge between a customer and the company. It is very often used as a topic-launcher (Erman 44). In this context we can talk of discourse markers as conversation monitors which signal the speakers are aware of their listeners' needs and monitor the state of shared knowledge:

$\mathrm{S}_{1}$ : We are always trying to help you, you know.

$\mathrm{S}_{2}$ : I am not quite sure, but if you say so...

$\mathrm{S}_{1}$ : I can assure you; your needs are our paramount interest.

If the speaker turns into a fact the implication that there is certain level of shared knowledge between him/her and the listener, this chunk can serve as a way of binding conversation participants, since shared knowledge helps establishing shared communicative space, which will further facilitate the conversation and, maybe ideally, empathy:

$\mathrm{S}_{1}$ : As I was saying, I completely understand your grievance, you know. I had the same problem some two months ago.

$\mathrm{S}_{2}$ : Really?

$\mathrm{S}_{1}$ : Sure, you know, when they switched me to the new IP service, everything was completely different.

$\mathrm{S}_{2}$ : I know.

S1: Right, let's turn to your IP address...

In this manner, you know serves as the tie, which connects and places both the speaker and the hearer into the shared space, since, as we 
can see from the example above, this sort of problem can happen to anyone. Furthermore, discourse markers indicate the levels of formality and people's feelings towards the interaction. Additionally, discourse markers help to organise the discourse. A marker such as Right, let's turn to... can indicate power relations in the sense that the power-role holder wants to manage both the discourse and its structure.

\section{Conclusions}

Through these numerous examples, we can see how speakers manage, soften or otherwise modify their messages. Most of this sort of discourse is both relational and transactional in its nature and its features, such as hedging, approximation and vagueness, are socially valuable. This type of research, which uses the context of professional discourse, may be valuable in language teaching in terms of cultural relativity of relational language and the importance of pragmatic awareness. For example, it could be examined how speech acts differ between different professions, and if they use different hedging devices. All of the examples from our paper belong to a small specialised corpus which helped us isolate specific contexts of interactions which would, otherwise, be lost in very large datasets of much bigger corpora, which may be understood as a compelling case for using small specialised corpora.

In our corpus, hedging is very important given the fact that it fulfils several different social and pragmatic functions. In our corpus, we found three dominant functions. First, hedges are useful for commenting on the content of a customer's proposition, where an agent lowers the risk of being rejected and, simultaneously, tries to be as accurate as possible. Second, agents and customers can express different degrees of certainty towards a proposition, which serves as a face-saving act, which is of vital importance. Third, all these elements facilitate the relationship between customers and agents.

The majority of the conversations from our corpus were symmetrical in terms of power relationship, since agents, who should be prototypical power-role holders, refrained from exercising this "right to power" in order to facilitate the conversation between themselves and the customers. Usually, turns were not pre-allocated, but tended to be short and often overlapping, where such overlapping literally supported the idea of the necessity to establish common ground in order to have more successful communication. Roles and goals were somewhat institutionalised and transactional in their nature, i.e. the main idea of the communication was to find more information about a 
specific problem or something similar, with an addition of other more affective elements which facilitate the communication process. Ritual brackets (openings, leaving, greeting, small talk, leave-taking and closings) were usually collaboratively negotiated.

\section{References}

Carter, R. A. and M. J. McCarthy. Cambridge Grammar of English: A Comprehensive Guide to Spoken and Written English Grammar and Usage. Cambridge: Cambridge University Press, 2006.

Channell, J. "Precise and vague quantities in writings on economics." Nash, W. The Writing Scholar. Newbury Park: Sage, 1990. 95117.

Cheepen, C. "Small talk in service dialogs: the conversational aspects of transactional telephone talk." Coupland, J. Small Talk. London: Longman, 2000. 288-311.

Coulmas, F. Conversational Routine. The Hague: Mouton, 1981.

Erman, B. Pragmatic Expressions in English: A Study of you know, you see, an I mean in Face-to-Face Conversation . Stockholm: Almqvist and Wiksell, 1987.

Goffman, E. Relations in Public: Micro-Studies of the Public Order. New York: Harper \& Row, 1971.

lacobucci, C. "Accounts, formulations and goal attainment strategies in service encounters." Tracy, K. and N. Coupland. Multiple Goals in Discourse. Clevedon: Multilungual Matters Ltd, 1990. 85-99.

Jucker, A. H., S. W. Smith and T. Ludge. "Interactive aspects of vagueness in conversation." Journal of Pragmatics (2003): 1737-1769.

Lakoff, G. "Hedges, a study in meaning criteria and the logic of fuzzy concepts." Papers from the Eight Regional Meeting, Chicago Linguistic Society (1972): 183-228.

O'Keeffe, A. Investigating Media Discourse. London: Routledge, 2006.

Oversteer, M. and G. Yule. "On being explicit and stuff in contemporary American English." Journal of English Linguistics (1997): 250258.

Paul Gee, J. Introducing Discourse Analysis - From Grammar to Society. Abingdon: Routledge, 2017.

Strauss, S. and F. Parastou. Discourse Analysis - Putting Our Worlds into Words. Abingdon: Routledge, 2014. 


\section{RELACIJSKI JEZIK KAO SREDSTVO UBLAŽAVANJA}

U ovom radu analiziraćemo i razgovarati o ideji relacijskog jezika. Pokušaćemo da dokažemo da riječi koje ispunjavaju istu semantičku ulogu unutar određenog semantičkog okvira imaju pragmatičku funkciju održavanja dobrih odnosa na relaciji govornik-slušalac i da omogućavaju nesmetano odvijanje razgovora, u ovom radu, između predstavnika telekomunikacione kompanije i korisnika. Ovakve učestale leksičke stavke ukazuju na nivo do kojeg govornici žele da idu na interaktivnoj ravni. Ove ideje smo primijenili na analizu korpusa koji smo prikupili putem transkripcije razgovora između predstavnika kompanije i korisnika. Razgovori se odvijaju u kontekstu pružanja različitih telekomunikacionih usluga, podnošenja pritužbi u vezi njih, kao i radi informisanja (mogućih) korisnika u vezi drugih pitanja i problema koje imaju.

Ključne riječi: relacijski jezik, jezička sredstva ublažavanja, neodređenost, aproksimacija 